\title{
ANALISIS SPASIAL DAN TEMPORAL KONDISI KUALITAS PERAIRAN MELALUI PENDEKATAN STATISTIK MULTIVARIAT DI TELUK GERUPUK PROVINSI NUSA TENGGARA BARAT
}

\author{
I Nyoman Radiarta ${ }^{\#}$ dan Erlania \\ Pusat Penelitian dan Pengembangan Perikanan Budidaya \\ (Naskah diterima: 5 Februari 2015; Revisi final: 25 Mei 2015, Disetujui publikasi: 2 September 2015)
}

\begin{abstract}
ABSTRAK
Kondisi kualitas perairan dipengaruhi oleh aktivitas antropogenik dan proses alami. Statistik multivariat, seperti analisis klaster (cluster analysis/CA) dan analisis komponen utama (principal component analysis/PCA), telah digunakan dalam penelitian ini untuk menganalisis kondisi kualitas perairan dan mengidentifikasi parameter kualitas air yang memengaruhi secara keruangan (spasial) dan waktu (temporal) di kawasan Teluk Gerupuk, Nusa Tenggara Barat. Data kondisi kualitas perairan di 16 titik pengamatan dikumpulkan selama enam bulan program pemantauan dari bulan Juli-Desember 2013. Hasil penelitian menunjukkan bahwa CA mengklasifikasikan enam bulan pengamatan menjadi dua periode; periode satu: Juli-September 2013, dan periode dua: Oktober-Desember 2013. Pengelompokkan ini berhubungan dengan pola musim tanam rumput laut di lokasi penelitian. CA juga mengklasifikasikan stasiun pengamatan menjadi tiga kelompok besar sesuai dengan kesamaan karakteristik kualitas air. PCA yang diaplikasikan pada seluruh data menghasilkan empat komponen utama dengan ragam kumulatif 69,93\%. Analisis PCA selama enam bulan pengamatan (Juli-Desember) menunjukkan bahwa parameter utama yang memengaruhi variasi kualitas air terutama adalah: suhu, $\mathrm{pH}$, dan konduktivitas. Penelitian ini menunjukkan efektivitas statistik multivariat untuk analisis dan interpretasi kondisi kualitas perairan baik secara spasial dan temporal. Pendekatan ini dapat berguna bagi pengelolaan dan evaluasi kondisi kualitas perairan.
\end{abstract}

KATA KUNCI: kualitas air, multivariat statistik, analisis klaster, analisis komponen utama, Teluk Gerupuk

ABSTRACT: Spatial and temporal analysis of water quality condition using multivariate statistical approach in Gerupuk Bay West Nusa Tenggara Province. By: I Nyoman Radiarta and Erlania

Water quality condition is affected by both anthropogenic activities and natural processes. Multivariate statistical techniques, such as cluster analysis (CA) and principal component analysis (PCA), were applied in this study for analyzing condition of water quality and identifying water quality variables responsible for spatial and temporal variations in Gerupuk Bay, West Nusa Tenggara. Water quality data in 16 stations were obtained during six months of monitoring program from July-December 2013. The results showed that CA classified six months into two periods; the first periods: July-September 2013 and second periods: October-December 2013. This groups were connected with planting seasons for seaweeds aquaculture. PCA analysis based on six months observation (July-December) indicate that the parameters responsible for water quality variations are mainly related to water temperature, $\mathrm{pH}$, dan conductivity. Thus, this study illustrates the utility of multivariate statistical techniques for analysis and interpretation of water quality in term of spatial and temporal variations. The approach could be valuable for evaluation of water quality condition and management.

KEYWORDS: $\quad$ water quality, mutivariate statistical, cluster analysis, principal component analysis, Gerupuk Bay

\# Korespondensi: Pusat Penelitian dan Pengembangan Perikanan Budidaya. Jl. Ragunan 20, Pasar Minggu, Jakarta Selatan 12540, Indonesia. Tel.: + (021) 7805052

E-mail: radiarta@yahoo.com 


\section{PENDAHULUAN}

Teluk Gerupuk merupakan salah satu kawasan pengembangan budidaya laut yang terletak di Kabupaten Lombok Tengah, Nusa Tenggara Barat. Teluk ini telah ditetapkan dalam program PIJAR (sapi, jagung, rumput laut) Provinsi Nusa Tenggara Barat sebagai kawasan pengembangan minapolitan rumput laut (Anonimous, 2012). Selain itu, Kawasan Teluk Gerupuk juga telah dijadikan lokasi percontohan pengembangan program ekonomi biru Kementerian Kelautan dan Perikanan (KKP, 2014). Produksi rumput laut di Teluk Gerupuk mengalami fluktuasi yang signifikan yaitu tahun 2009 produksi rumput laut kering mencapai 13.300 ton, namun produksi tersebut terus mengalami penurunan tahun 2010 dan 2011 yaitu 10.228,51 ton dan 8.266,99 ton (Anonimous, 2012). Fluktuasi produksi tersebut dapat disebabkan karena berbagai hal di antaranya kondisi lingkungan perairan dan iklim yang sangat memengaruhi pola musim tanam rumput laut (Pong-Masak et al., 2009; Parenrengi et al., 2011; Radiarta et al., 2013b).

Kondisi kualitas perairan dipengaruhi oleh aktivitas antropogenik dan proses alami. Proses alam yang memengaruhi kualitas air meliputi tingkat curah hujan, proses pelapukan, dan transportasi sedimen, sedangkan kegiatan antropogenik termasuk pembangunan dan perluasan daerah pemukiman, serta kegiatan industri, perikanan, dan pertanian. Kegiatan ini sering mengakibatkan degradasi kualitas air, habitat fisik, dan kondisi biologinya. Sehubungan dengan hal ini, program pemantauan secara berkelanjutan terhadap parameter utama kualitas perairan sangat diperlukan, guna menghasilkan estimasi kondisi kualitas perairan secara representatif dan komprehensif (Butler et al., 2001; Radiarta et al., 2014a). Tujuan utama pemantauan kualitas perairan adalah untuk mengontrol dan meminimalkan dampak yang ditimbulkan dari perubahan kondisi perairan sehingga dapat menghasilkan air dengan kualitas standar bagi penggunanya, seperti misalnya air minum, irigasi, perikanan budidaya, dan pariwisata (Boyacioglu, 2006). Sistem pemantauan kualitas air yang tidak dirancang dengan baik, tentunya kurang memberikan informasi yang berguna tentang kondisi perairan. Oleh sebab itu, langkah analisis berupa klasifikasi, pemodelan, dan interpretasi pemantauan data kualitas air merupakan tahapan penting dalam penilaian kualitas air.

Teknik statistik multivariat telah diterapkan untuk mengkarakterisasi dan mengevaluasi kondisi kualitas perairan, karena teknik tersebut berguna untuk verifikasi variasi waktu (temporal) dan ruang (spasial) yang disebabkan oleh faktor alam dan antropogenik terkait dengan musim. Beberapa peneli- tian telah mengaplikasikan statistik multivariat pada berbagai ekosistem yang berbeda yaitu danau (Iscen et al., 2008; Kazi et al., 2009), daerah aliran sungai (Singh et al., 2004; Shrestha \& Kazama, 2007; Mohamed et al., 2015), dan perairan pesisir (Kim et al., 2005; Kamble \& Vijay, 2011; Erlania \& Radiarta, 2011). Statistik multivariat yang banyak digunakan adalah analisis klaster, analisis komponen utama, dan analisis faktor. Analisis tersebut digunakan dengan tujuan membantu dalam interpretasi matriks data yang komplek sehingga lebih memahami kualitas air, serta status ekologi dari sistem yang dipelajari. Hasil analisis kadang-kadang membuat variabel baru dengan mengurangi jumlah variabel asli dalam perbandingan dan interpretasi data (Ragno et al., 2007).

Dalam penelitian ini, data yang diperoleh selama enam bulan program pemantauan menjadi objek dari statistik multivariat yang berbeda untuk menganalisis kondisi kualitas perairan dan mengidentifikasi parameter kualitas air yang memengaruhi secara keruangan (spasial) dan waktu (temporal) di kawasan Teluk Gerupuk, Nusa Tenggara Barat. Pendekatan statistik multivariat yang digunakan dalam penelitian ini meliputi analisis klaster dan analisis komponen utama. Hasil analisis klaster kemudian dipetakan secara spasial dengan menggunakan aplikasi sistem informasi geografis (SIG).

\section{BAHAN DAN METODE}

\section{Lokasi Penelitian dan Pengumpulan Data}

Penelitian dilaksanakan di Teluk Gerupuk Kabupaten Lombok Tengah, Nusa Tenggara Barat (Gambar 1). Total luasan perairan kawasan penelitian mencapai 834 ha. Karakteristik perairan di dalam teluk yang cukup terlindung dan relatif dangkal menjadikan perairan ini sangat berpotensi untuk pengembangan budidaya laut. Kawasan Teluk Gerupuk telah dimanfaatkan untuk berbagai aktivitas di antaranya perikanan budidaya (rumput laut, ikan, dan lobster), perikanan tangkap (pengumpul benih lobster alam), dan pariwisata (berselancar/surfing). Aktivitas penangkapan benih lobster alam belakangan ini semakin pesat dilakukan di kawasan ini. Berdasarkan Radiarta \& Rasidi (2012) luas kawasan pemanfaatan perairan di Teluk Gerupuk adalah sekitar 220 ha untuk keramba jaring apung ikan laut dan lobster yang tersebar di bagian Barat laut dan Timur laut teluk, sekitar 150 ha untuk surfing terletak di bagian Utara dan Barat teluk, dan sekitar 322 ha untuk budidaya rumput laut yang umumnya terletak di tengah-tengah teluk dengan karakteristik perairan yang cukup bersih. Kecepatan arus berkisar antara 1,25-7,50 cm/dt; dan tinggi gelombang antara 0,06-0,9 m (Radiarta et al., 2013a). Aktivitas budidaya rumput laut di kawasan ini 


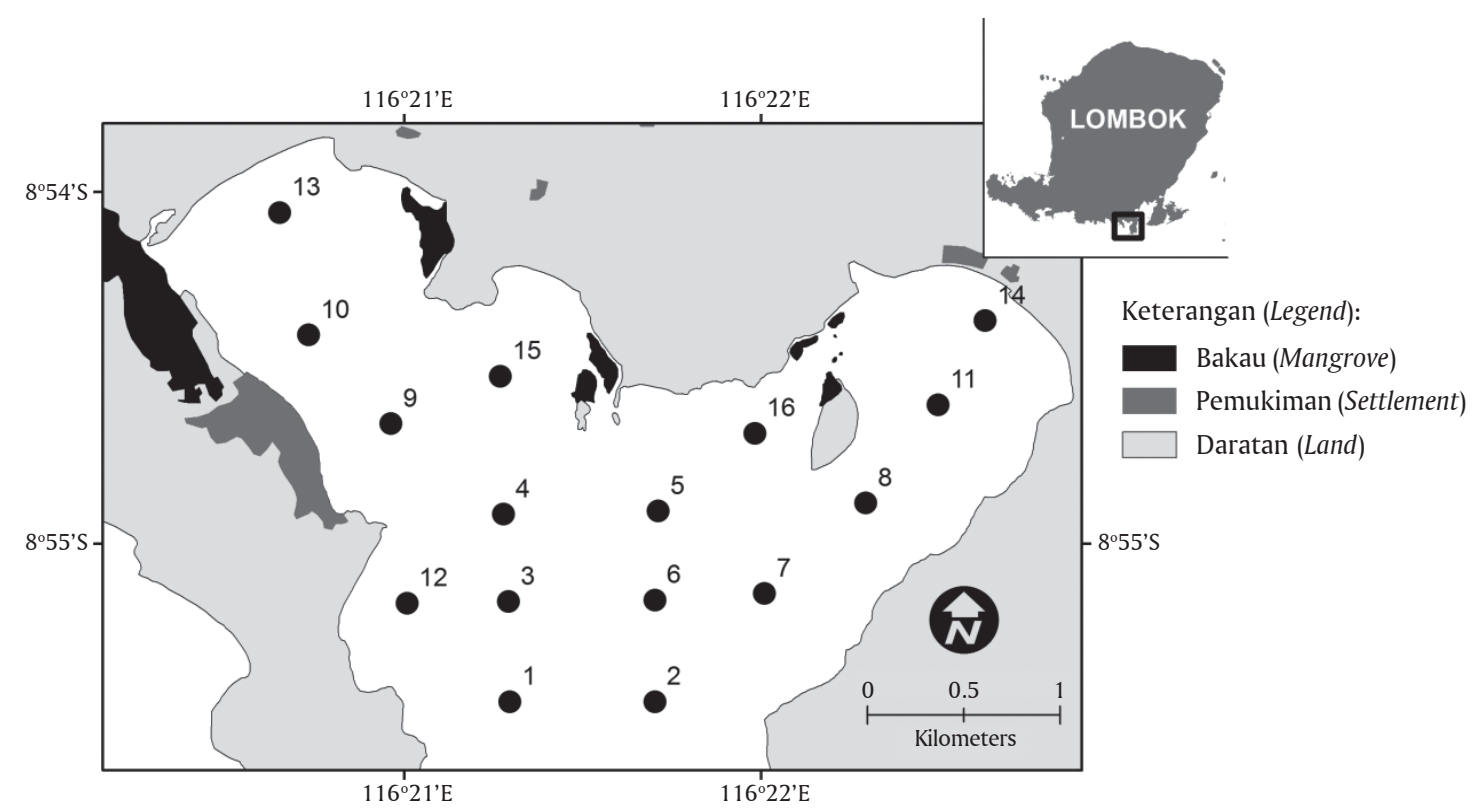

Gambar 1. Peta lokasi penelitian dan lokasi pengamatan kualitas air di Teluk Gerupuk, Lombok Tengah, NTB. Angka menunjukkan stasiun pengamatan kualitas air

Figure 1. Map showing the study area and location of water quality sampling stations in Gerupuk Bay, Central Lombok, NTB. Numbers indicate the location for water quality sampling

selain dipengaruhi oleh karakteristik perairan juga dipengaruhi oleh kondisi iklim lokal ataupun global (Radiarta et al., 2013b).

Pengumpulan data kualitas perairan dilakukan pada bulan Juli-Desember 2013. Data dikumpulkan dari 16 stasiun yang tersebar merata di lokasi penelitian (Gambar 1). Pengukuran kualitas air dan pengambilan contoh air dilakukan di permukaan perairan $(<1 \mathrm{~m})$ dan pada kisaran waktu 9:00-15:00 waktu setempat. Parameter kualitas air yang dikumpulkan meliputi: suhu, salinitas, $\mathrm{pH}$, oksigen terlarut (DO), padatan terlarut (TDS), konduktivitas, padatan tersuspensi (TSS), amonia $\left(\mathrm{NH}_{3}-\mathrm{N}\right)$, nitrit $\left(\mathrm{NO}_{2}-\mathrm{N}\right)$, dan fosfat $\left(\mathrm{PO}_{4}^{-} \mathrm{P}\right)$. Parameter suhu, salinitas, $\mathrm{pH}, \mathrm{DO}, \mathrm{TDS}$, dan konduktivitas diukur langsung di lapangan menggunakan YSI Profesional +; sedangkan parameter lainnya dianalisis di Laboratorium Pengujian Balai Budidaya Laut Lombok di Sekotong. Metode pengambilan, preservasi, dan analisis contoh air mengacu pada metode standar APHA (2005).

\section{Perlakuan Data dan Analisis Statistik Multiva- riat}

Analisis statistik multivariat digunakan untuk klasifikasi, pembentukan model, dan interpretasi kumpulan data dengan multi-parameter yang diperoleh dari hasil pemantauan lingkungan perairan, yang bertujuan untuk memudahkan dalam menyederhanakan kompleksitas data dan mengekstrak informasi sehingga berguna bagi pendugaan kondisi kualitas perairan dan pengelolaannya. Sebelum melakukan anali- sis statistik multivariat, perlu dilakukan analisis pola distribusi atau uji normalitas dan proses standarisasi data yang akan digunakan. Dalam rangka menganalisis pola distribusi paramater kualitas air, analisis korelasi Pearson telah digunakan untuk melihat hubungan antar parameter yang digunakan dalam analisis. Selain itu, pendekatan dengan korelasi Sperman-R dapat juga digunakan (Shrestha \& Kazama, 2007; Varol \& Sen, 2009). Analisis data kondisi perairan dari bulan Juli-Desember yang merepresentasikan variasi perbedaan waktu pengamatan; dan lokasi pengamatan yang merepresentasikan variasi spasial; dilakukan dengan analisis klaster (cluster analysis/CA).

CA adalah kelompok dari analisis multivariat yang tujuan utamanya adalah untuk mengklasifikasikan objek berdasarkan karakteristik yang mereka miliki. CA dilakukan pada data yang telah distandarisasi melalui transformasi skala-Z (Z-scale). Transformasi ini digunakan untuk menghindari klasifikasi yang salah disebabkan karena variasi satuan dari masing-masing parameter kualitas air; selain itu, melalui standarisasi ini dapat meningkatkan pengaruh parameter yang memiliki varian yang kecil dan sebaliknya memperkecil pengaruh parameter dengan varian yang besar (Varol \& Sen, 2009). CA mengklasifikasikan objek sehingga objek yang serupa akan dikelompokkan dalam klaster yang sama, sesuai dengan kriteria yang digunakan (Varol \& Sen, 2009; Kamble \& Vijay, 2011). Hasil CA dari sekelompok objek harus menunjukkan kesamaan yang tinggi di dalam klaster dan ketidak- 
samaan yang tinggi antara klaster. Pada penelitian ini, hierarchical agglomerative clustering dengan metode Ward (Ward's method) dan squared Euclidean distances adalah metode CA yang digunakan untuk mengukur tingkat kesamaan objek. Hasil CA dapat digambarkan dalam bentuk dendogram (diagram pohon). Hasil CA yang diperoleh kemudian dipetakan secara spasial dengan menggunakan ArcGIS v.10. Analisis ini dilakukan dengan teknik interpolasi inverse distance weighted/IDW (Johnson \& McChow, 2001).

Hasil analisis terhadap awal data kualitas air menunjukkan bahwa nilai Kaiser-Meyer-Olkin (KMO) adalah 0,575. Nilai KMO yang cukup besar (mendekati 1) mengindikasikan bahwa analisis komponen utama (Principal component analysis/PCA) berguna untuk melihat karakteristik kualitas air. PCA dirancang untuk mengubah parameter asli ke parameter baru yang tidak berkolerasi, yang disebut komponen utama, yaitu berupa kombinasi linear dari parameterparameter asli. PCA memberikan cara yang obyektif untuk menemukan indeks jenis parameter baru ini sehingga variasi dalam data dapat dipertanggungjawabkan sebagai seringkas mungkin (Shrestha \& Kazama, 2007; Iscen et al., 2008; Varol \& Sen, 2009). PCA akan menghasilkan nilai akar ciri (eigenvalues) dan eigenvectors dari matrik covarian parameter asli. Komponen utama yang terkecil umumnya dipilih (misalnya komponen 1, 2, atau 3); karena mengandung banyak informasi yang dapat menjelaskan keragaman dari parameter asli (Boyacioglu, 2006).

Selain analisis CA dan PCA, data karakteristik kondisi kualitas air yang dikumpulkan selama penelitian juga dianalisis secara statistik deskriptif. Analisis ini dilakukan guna memperoleh gambaran umum tentang kondisi kualitas perairan di lokasi penelitian. Seluruh analisis data dilakukan dengan SPSS v.19.0.

\section{HASIL DAN BAHASAN}

\section{Kondisi Kualitas Perairan}

Kawasan Teluk Gerupuk telah dimanfaatkan untuk berbagai aktivitas di antaranya budidaya laut, pariwisata, dan penangkapan. Seluruh aktivitas tersebut, dan berbagai aktivitas di daratan (antropogenik) akan memengaruhi kondisi kualitas perairan secara spasial dan temporal. Pemantauan terhadap kondisi kualitas perairan merupakan tahapan penting yang harus dilakukan untuk mendukung pengelolaan dan pemanfaatan perairan secara baik, di antaranya untuk budidaya laut. Statistik deskriptif, meliputi kisaran, rataan, dan standar deviasi (SD), hasil pengamatan kualitas perairan di 16 titik pengamatan selama enam bulan disajikan pada Tabel 1. Kore- lasi antara parameter kualitas air juga dianalisis untuk mengetahui hubungan antara parameter kualitas air tersebut (Tabel 2). Data kualitas air yang diidentifikasi dalam penelitian ini meliputi parameter fisik dan kimia perairan.

Parameter fisik yang diamati meliputi: suhu air, padatan terlarut (TDS), konduktivitas, dan padatan tersuspensi (TSS), masih sesuai dengan baku mutu air untuk biota laut (KLH, 2004). Rataan suhu air selama enam bulan pengamatan adalah $28,57^{\circ} \mathrm{C} \pm 1,45^{\circ} \mathrm{C}$; dengan kisaran $26,50^{\circ} \mathrm{C}-32,10^{\circ} \mathrm{C}$. Suhu perairan mengalami tren peningkatan mulai bulan Juli-Desember, dengan suhu maksimum tercatat pada bulan Oktober. Hal ini disebabkan karena tingginya suhu udara dan rendahnya curah hujan yang terjadi (Radiarta et al., 2013b; Erlania \& Radiarta, 2014). Tingginya suhu perairan yang terjadi di Teluk Gerupuk ini telah memengaruhi pertumbuhan rumput laut yang dibudidayakan, di mana pada bulan November-Desember 2013 masuk dalam kategori musim tanam tidak produktif untuk budidaya rumput laut (Erlania \& Radiarta, 2014). Nilai korelasi Pearson menunjukkan bahwa suhu air berkorelasi dengan $\mathrm{pH}(\mathrm{r}=0,68$; $\mathrm{P}<0,01)$ dan konduktivitas $(\mathrm{r}=0,90 ; \mathrm{P}<0,01)$. Rataan konduktivitas adalah 56,69 $1,63 \mathrm{mS} / \mathrm{cm}$; dengan kisaran 54,25-61,64 mS/cm. Nilai rataan TDS adalah 34,52 $\pm 0,38 \mathrm{mg} / \mathrm{L}$; dengan kisaran 31,65-35,50 mg/L. Konduktivitas memiliki korelasi positif dengan $\mathrm{pH}$ air $(r=0,57 ; \mathrm{P}<0,01)$ dan TDS $(\mathrm{r}=0,42 ; \mathrm{P}<0,01)$. Korelasi yang tinggi antara konduktivitas dan TDS juga ditemukan oleh Shuhaimi-Othman et al. (2007) dalam kajiannya tentang kondisi kualitas air di Danau Chini, Malaysia.

Parameter kimia perairan yang diamati dalam penelitian ini meliputi: $\mathrm{pH}$ air, DO, dan salinitas. Nilai rataan $\mathrm{pH}$ air yang terukur adalah $8,27 \pm 0,08$; dengan kisaran 7,97-8,46. Kisaran $\mathrm{pH}$ ini masih masuk dalam kisaran baku mutu air laut untuk biota laut (KLH, 2004). Hasil pengukuran $\mathrm{pH}$ air selama enam bulan pengamatan menunjukkan bahwa parameter ini cenderung mengalami peningkatan dari bulan Juli hingga Desember (Tabel 1). Nilai kisaran DO adalah $5,67-10,26 \mathrm{mg} / \mathrm{L}$ dengan rataan $6,98 \pm 0,78 \mathrm{mg} / \mathrm{L}$. Kisaran DO ini masih layak untuk budidaya ikan laut dalam keramba jaring apung (Beveridge, 1996). DO memiliki korelasi dengan $\mathrm{pH}(\mathrm{r}=0,28$; $\mathrm{P}<0,01)$. Rataan salinitas yang terukur selama penelitian adalah $34,93 \pm 0,44$ ppt; dengan kisaran 31,57-35,75 ppt. Kisaran sanilitas ini masih baik untuk aktivitas budidaya laut. Kisaran salinitas yang ideal untuk budidaya rumput laut adalah 32-34 ppt (Parenrengi et al., 2011). Salinitas memiliki korelasi yang tinggi dengan TDS ( $r=0,99 ; P<0,01)$ dan konduktivitas $(r=0,31$; $\mathrm{P}<0,01)$. 


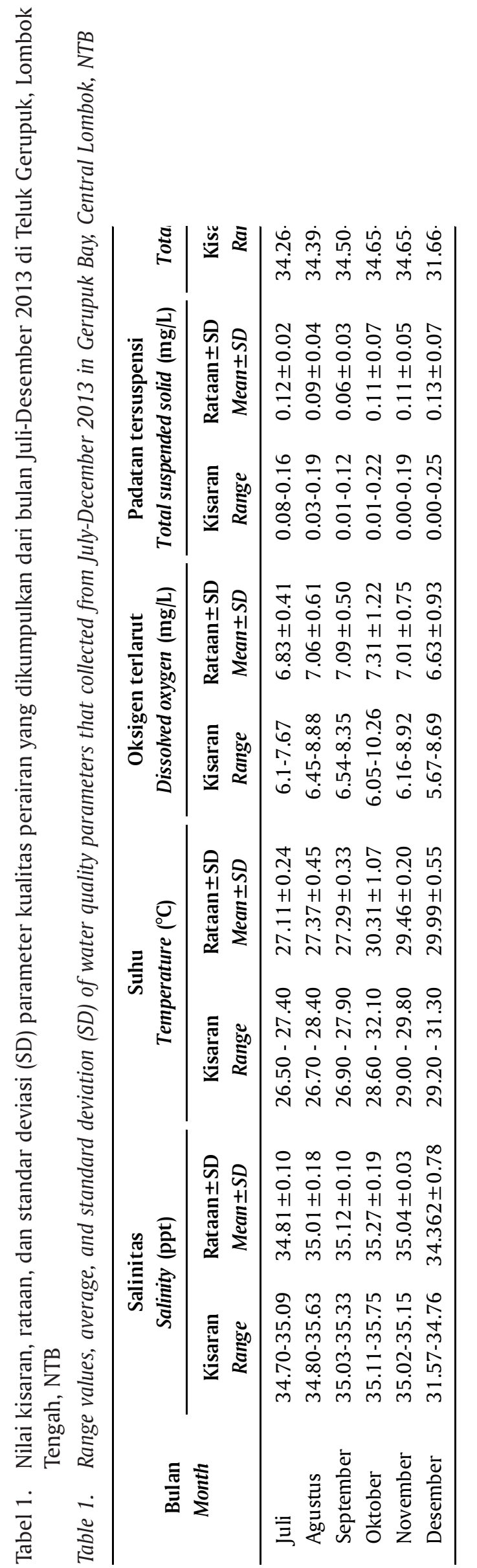

\begin{tabular}{|c|c|c|}
\hline $\begin{array}{l}\square \\
\frac{5}{5}\end{array}$ & 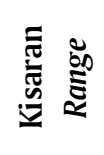 & 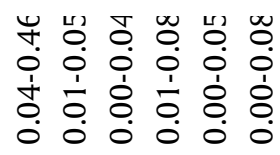 \\
\hline 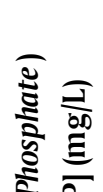 & 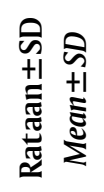 & 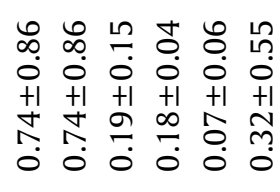 \\
\hline 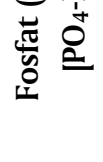 & 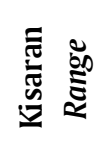 & 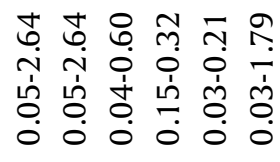 \\
\hline 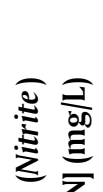 & 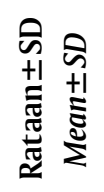 & 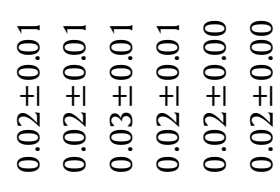 \\
\hline 吾 & 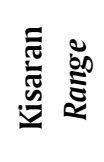 & 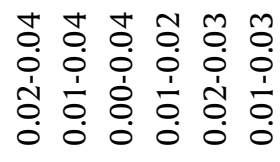 \\
\hline 氦 & 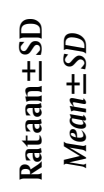 & $\begin{array}{llllll}\sigma & \overline{0} & \tilde{0} & \tilde{0} & \tilde{0} & \overline{0} \\
0 & 0 & 0 & 0 & 0 & 0 \\
+1 & +1 & +1 & +1 & +1 & +1 \\
\tilde{0} & \tilde{0} & 0 & \tilde{0} & \tilde{0} & \tilde{0} \\
0 & 0 & 0 & 0 & 0 & 0\end{array}$ \\
\hline 亭 & 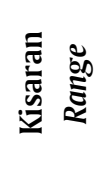 & 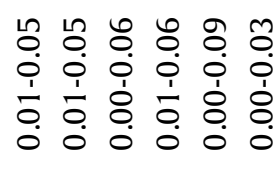 \\
\hline 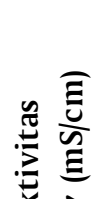 & 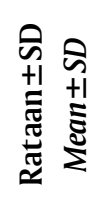 & 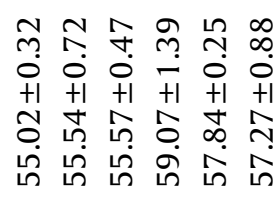 \\
\hline 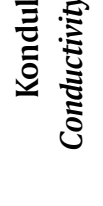 & 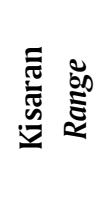 & 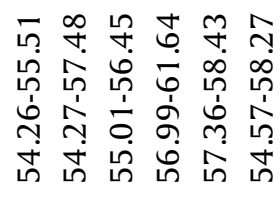 \\
\hline & 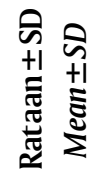 & 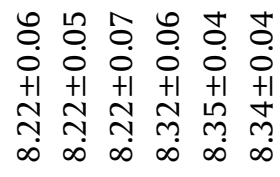 \\
\hline & 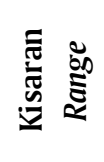 & 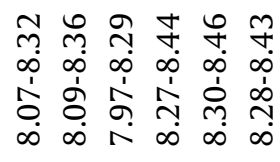 \\
\hline
\end{tabular}




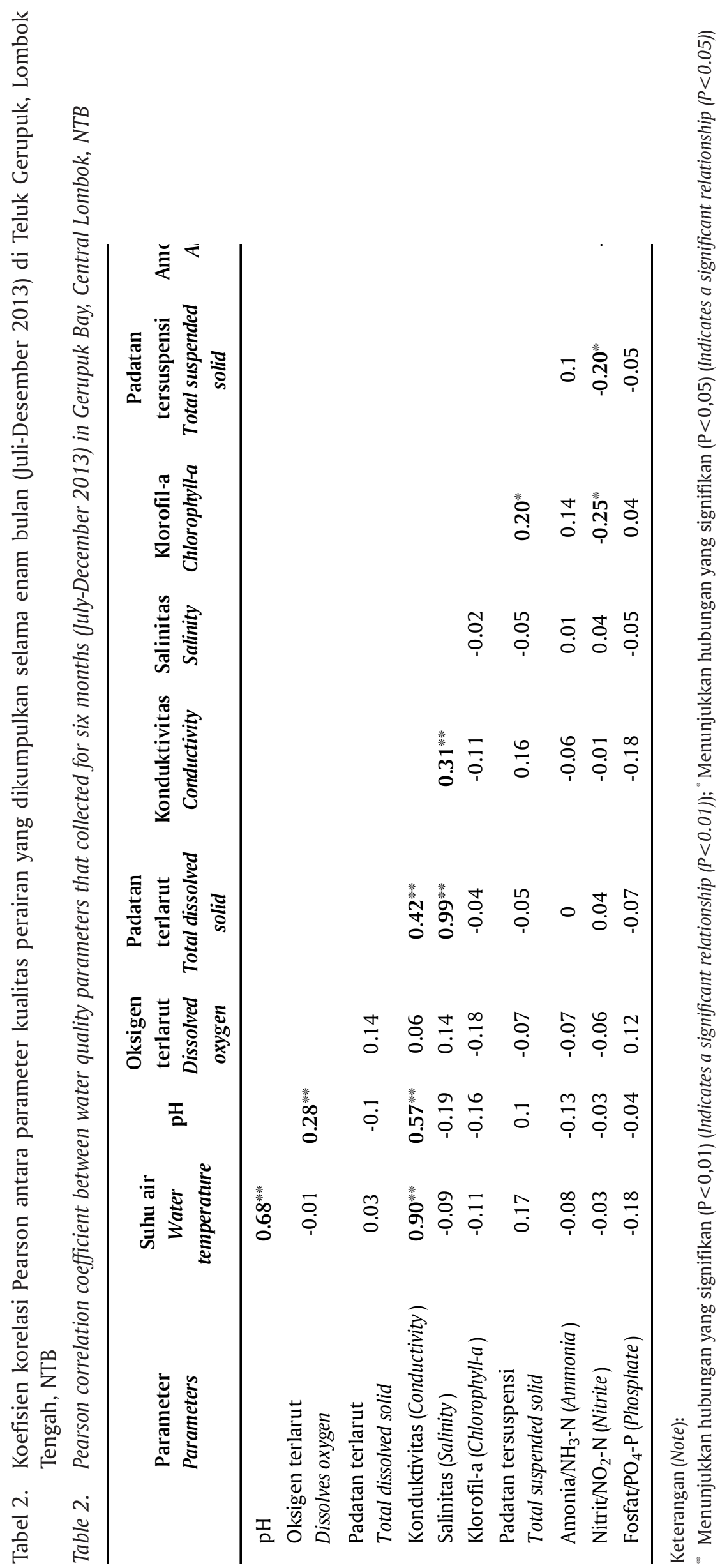


Amonia, nitrit, fosfat, dan klorofil-a merupakan parameter kesuburan perairan yang diamati pada penelitian ini. Untuk aktivitas budidaya rumput laut, amonia, nitrit, dan fosfat, merupakan parameter penting untuk mendukung pertumbuhan rumput laut (Neori, 2007; Radiarta et al., 2014b). Ketersediaan kandungan ketiga parameter ini di alam sangat kecil, sehingga sering kali menjadi faktor pembatas bagi pertumbuhan rumput laut, ataupun aktivitas budidaya laut lainnya. Kisaran amonia, nitrit, dan fosfat yang terukur di lokasi penelitian secara berturut-turut adalah $0,023 \pm 0,015 \mathrm{mg} / \mathrm{L} ; 0,022 \pm 0,008 \mathrm{mg} / \mathrm{L}$; dan $0,288 \pm 0,476 \mathrm{mg} / \mathrm{L}$. Nitrit memiliki korelasi negatif dengan amonia $(r=-0,34 ; P<0,01)$. Pada siklus nitrogen, amonia mengalami oksidasi menjadi nitrit dan nitrat melalui proses nitrifikasi (Effendi, 2003). Selain itu, nitrit juga memiliki korelasi negatif dengan beberapa parameter lainnya yaitu klorofil-a $(\mathrm{r}=$ $-0,25 ; \mathrm{P}<0,05)$, TSS $(\mathrm{r}=-0,20 ; \mathrm{P}<0,05)$. Nilai korelasi negatif ini menunjukkan bahwa bahan organik di perairan akan terurai menjadi senyawa anorganik dalam bentuk ion-ion seperti amonium nitrat, nitrit, dan fosfat. Ion-ion anorganik ini akan dimanfaatkan oleh tumbuhan air termasuk fitoplankton sebagai komponen penentu nilai klorofil di perairan, sehingga kandungan nitrogen di perairan akan berkorelasi negatif dengan klorofil-a (Dawes, 1981; Effendi, 2003; Nontji, 2008). Nilai klorofil-a cukup berfluktuasi di lokasi penelitian, dengan kisaran $0,00-0,45 \mathrm{mg} / \mathrm{L}$ dan rataan $0,039 \pm 0,058 \mathrm{mg} / \mathrm{L}$. Nilai klorofil-a tertinggi ditemukan pada bulan Oktober 2013. Kandungan klorofil-a yang tinggi menunjukkan tingginya kelimpahan fitoplankton di perairan tersebut. Dapat dikatakan bahwa perairan yang produktivitas primer fitoplanktonnya tinggi akan mempunyai potensi sumberdaya hayati yang besar (Nontji, 2008).

\section{Analisis Klaster}

Analisis klaster (CA) dalam penelitian ini digunakan untuk mengklasifikasikan kondisi kualitas perairan berdasarkan spasial dan temporal (waktu). Analisis berdasarkan waktu dari CA yang ditampilkan dalam bentuk dendogram (Gambar 2), membagi enam bulan pengamatan menjadi dua periode berdasarkan karakteristik kualitas air pada masing-masing waktu pengamatan. Periode pertama yaitu bulan Juli-September 2013. Pada bulan tersebut umumnya memiliki karakteristik curah hujan rendah, kecepatan angin sedang, dan suhu udara yang relatif rendah. Klaster ini sangat relevan dengan musim tanam rumput laut yang produktif. Laju pertumbuhan harian rumput laut yang dibudidayakan pada kisaran bulan tersebut mencapai rata-rata $>4 \% /$ hari (Erlania \& Radiarta, 2014). Periode kedua yaitu bulan Oktober-Desember 2013, merupakan bulan tidak produktif untuk budi- daya rumput laut. Curah hujan ditemukan cukup tinggi pada bulan tersebut terutama bulan November dan Desember 2013. Curah hujan yang tinggi ini akan memengaruhi kondisi masa air dan salinitas perairan. Dengan menurunnya salinitas dan banyaknya curah hujan dapat menyebabkan penyakit (ice-ice) pada budidaya rumput laut (Parenrengi et al., 2011; Radiarta et al., 2013b). Pada kisaran bulan tersebut, laju pertumbuhan rumput laut yang dibudidayakan adalah $<3 \%$ /hari (Erlania \& Radiarta, 2014).

Secara spasial, CA mengelompokkan 16 stasiun pengamatan menjadi tiga klaster yang berbeda (Gambar 3), sesuai dengan karakteristik kualitas perairan di masing-masing stasiun pengamatan. Gambar 4 menyajikan analisis spasial CA terhadap 16 stasiun pengamatan. Klaster pertama terdiri atas stasiun 1-9 dan 15. Secara umum klaster ini menggambarkan lokasi-lokasi yang dicirikan dengan karakteristik kedalaman yang relatif hampir sama dan merupakan kisaran kedalaman yang sesuai untuk pengembangan budidaya laut. Pada lokasi-lokasi yang termasuk dalam klaster ini telah banyak berkembang aktivitas masyarakat di antaranya budidaya rumput laut, budidaya ikan laut, dan penangkapan benih lobster alam. Hasil analisis spasial dan temporal kelayakan lahan budidaya rumput laut (Radiarta \& Erlania, 2014), menunjukkan bahwa lokasi-lokasi tersebut sangat berpotensi untuk pengembangan budidaya laut. Klaster kedua terdiri atas stasiun pengamatan 10,11,13, dan 14. Kawasan dalam klaster ini umumnya merupakan kawasan dangkal yang didominasi oleh lumpur (bagian dalam teluk) dan pantai berbatu karang. Kawasan bagian dalam teluk (Teluk Gerupuk dan Teluk Bumbang) umumnya banyak dimanfaatkan untuk penangkapan benih lobster alam (Erlania et al., 2014). Klaster ketiga yang terdiri atas stasiun 12 dan 16, merupakan kawasan dangkal dengan pantai berpasir. Perairan ini umumnya didominasi oleh pecahan karang dan padang lamun. Untuk pengembangan budidaya laut, kawasan dalam klaster ini dapat dikembangkan untuk budidaya teripang.

Pemanfaatan CA terhadap kualitas air untuk melihat karakteristik kawasan telah banyak diaplikasikan (Varol \& Sen, 2009; Juahir et al., 2011; Huang et al., 2011). CA dapat memberikan informasi yang berguna tentang klasifikasi kawasan sehingga dapat digunakan untuk mendesain pemantauan kualitas air secara maksimal dan komprehensif. Strategi ini dapat ditempuh dalam rangka menghemat waktu, tenaga, dan biaya.

\section{Analisis Komponen Utama}

PCA diaplikasikan pada seluruh data (11 parameter) dari 16 titik pengamatan dengan tujuan untuk 
Dendogram using Ward Linkage Rescale Distance Cluster Combine

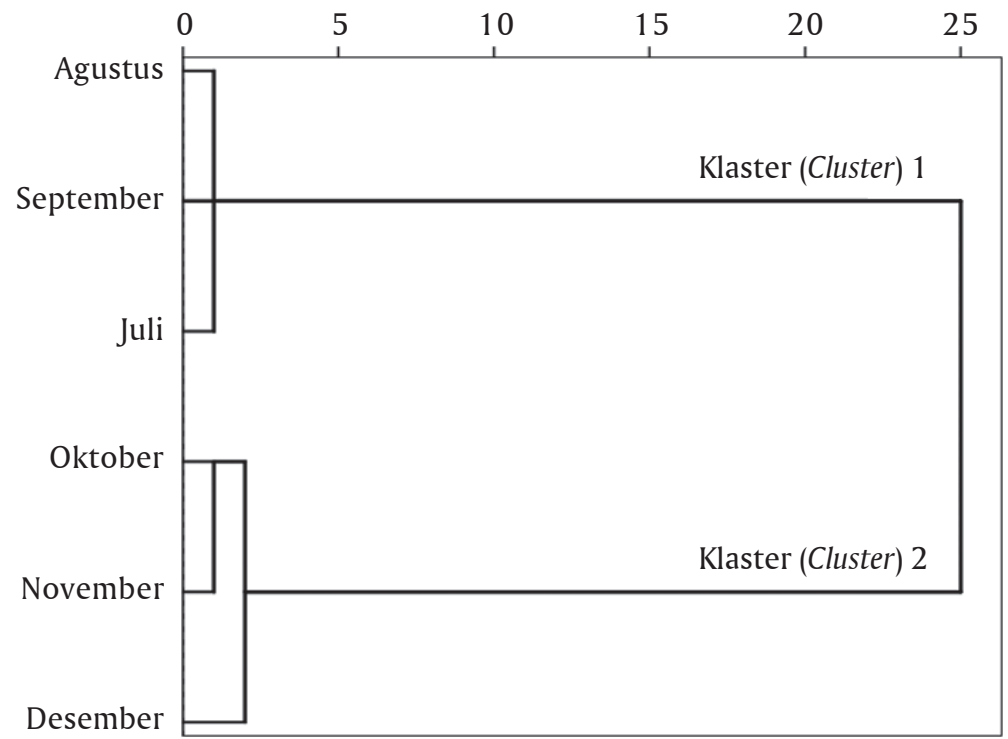

Gambar 2. Dendrogram menunjukkan pengelompokan berdasarkan waktu pengamatan kualitas perairan di Teluk Gerupuk, Lombok Tengah, NTB

Figure 2. Dendrogram showing clustering of monitoring periods of water quality in Gerupuk Bay, Central Lombok, NTB

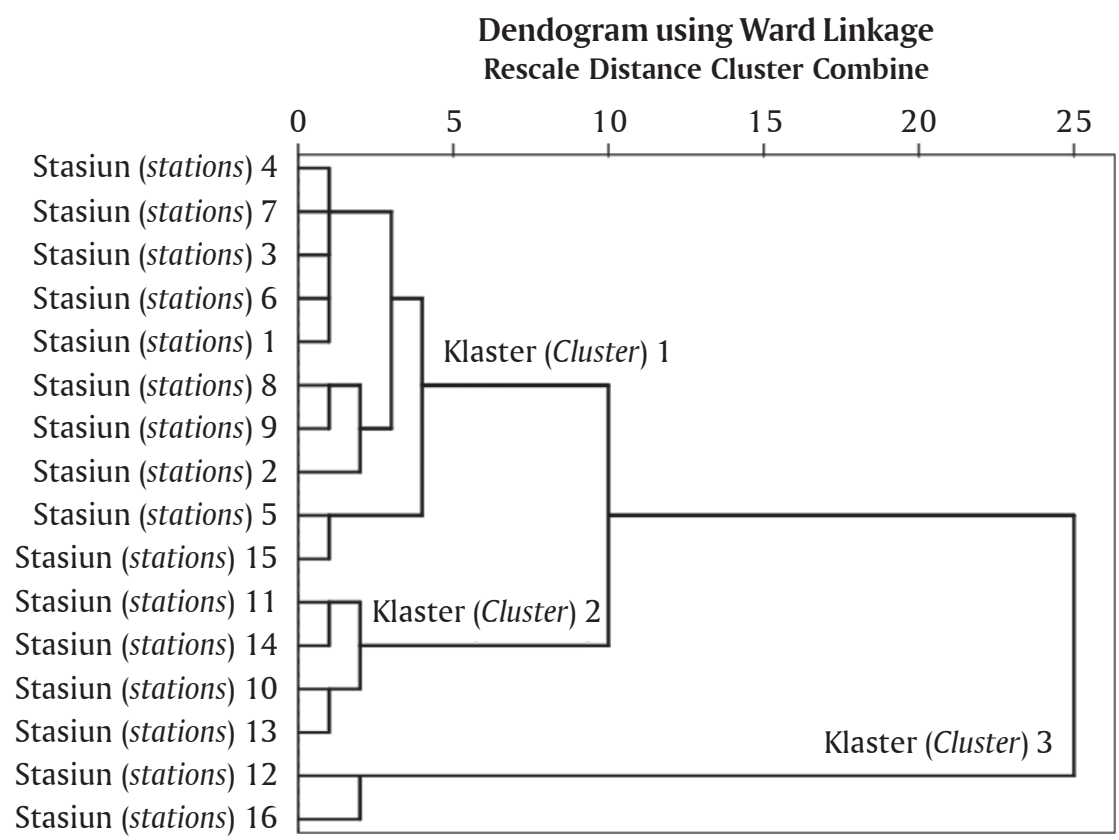

Gambar 3. Dendrogram menunjukkan pengelompokan berdasarkan lokasi pengamatan kualitas perairan di Teluk Gerupuk, Lombok Tengah, NTB

Figure 3. Dendrogram showing clustering of monitoring sites of water quality in Gerupuk Bay, Central Lombok, NTB

mengidentifikasi parameter kualitas air yang memengaruhi lokasi penelitian. Seluruh komponen utama (principal component/PC) yang dihasilkan dari PCA ditampilkan pada Gambar 5. Dari seluruh komponen utama tersebut, hanya empat komponen yang berperan penting dengan nilai akar ciri (eigenvalue) $>1$
(Iscen et al., 2008; Varon \& Sen, 2009). Nilai akar ciri memberikan ukuran tentang pentingnya PC; PC dengan nilai akar ciri tertinggi adalah yang paling signifikan mewakili karakteristik perairan. Nilai akar ciri yang besar $(>1,0)$ digunakan untuk menentukan jumlah PC yang dianggap dapat mewakili seluruh va- 


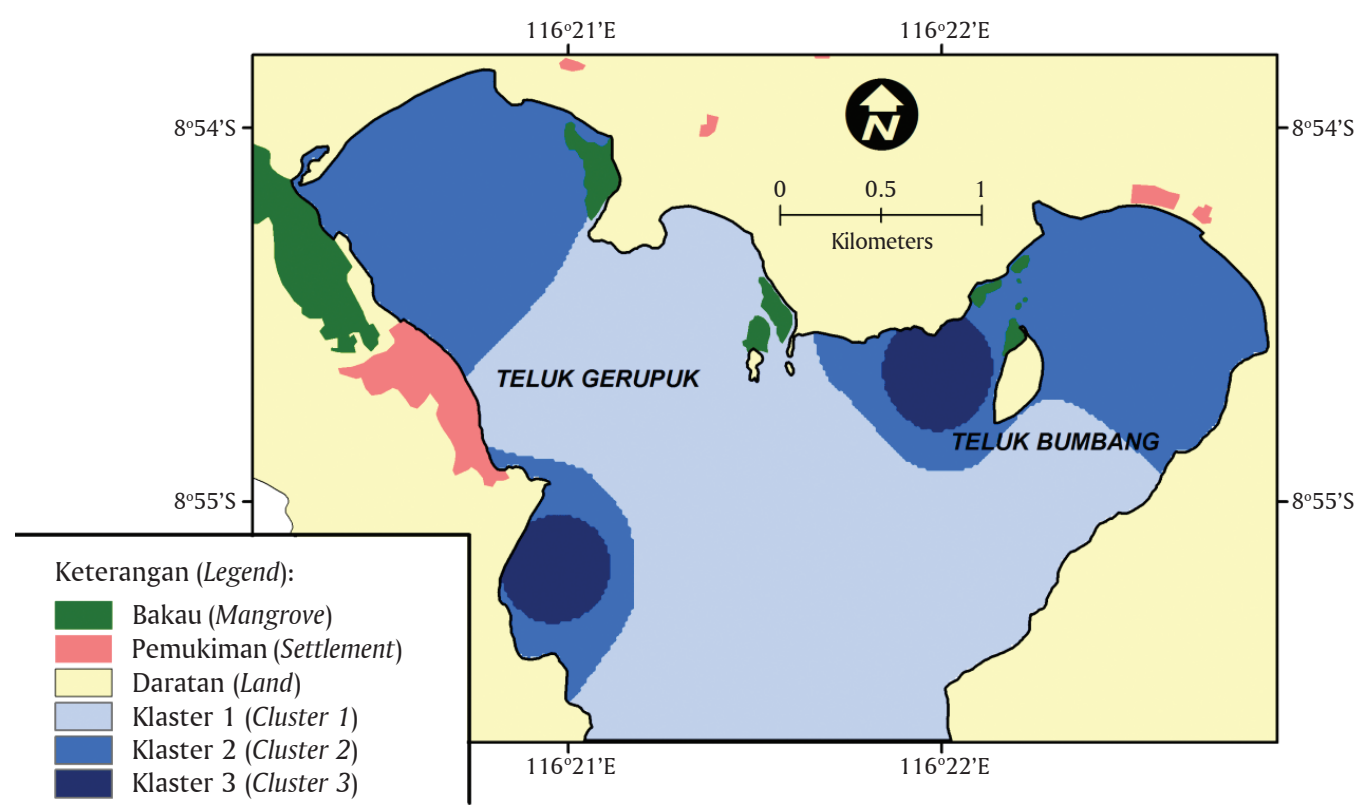

Gambar 4. Peta pengelompokkan wilayah perairan berdasarkan lokasi pengamatan kualitas perairan di Teluk Gerupuk, Lombok Tengah, NTB

Figure 4. Map of water classification based on clustering of monitoring sites of water quality parameters in Gerupuk Bay, Central Lombok, NTB

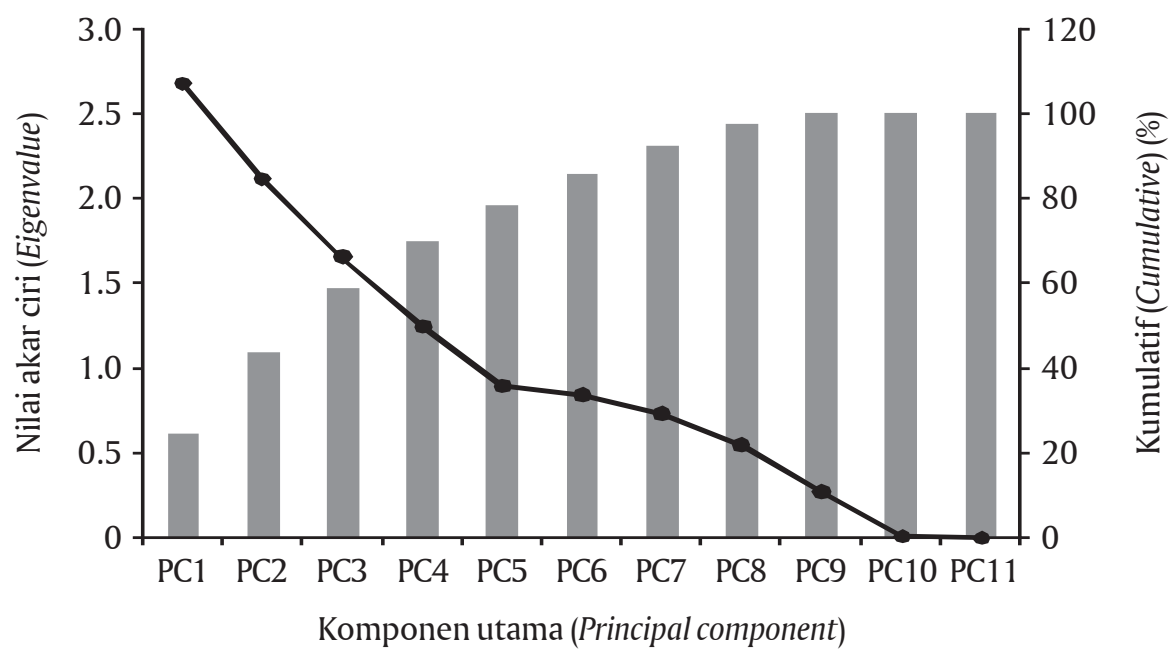

Gambar 5. Nilai akar ciri dan persentase ragam kumulatif dari analisis komponen utama

Figure 5. Eigenvalues and percentage of cumulative of variance from principal component analysis

riabel (Shrestha \& Kazama, 2007). Hasil PCA menunjukkan bahwa terdapat 4 PC pertama yang dianggap dapat menggambarkan karakteristik perairan Teluk Gerupuk, keempat PC tersebut secara kumulatif dapat menjelaskan ragam seluruh data sebesar $69,96 \%$ (Tabel 3).

Liu et al. (2003) mengelompokkan hasil PCA menjadi tiga kelompok berdasarkan nilai muatan PC (factor loading) yaitu kuat $(>0,75)$; sedang $(0,50-0,75)$; dan lemah $(0,30-0,50)$. Berdasarkan pengelompokkan tersebut, hasil analisis PC terhadap seluruh parameter kualitas perairan pada penelitian ini hanya memperhatikan kategori kuat dan sedang (Tabel 3; Gambar 6). Karakteristik PC1 yang menyumbang 24,30\% dari total ragam, dibangun oleh interaksi tiga parameter utama dengan nilai muatan yang relatif besar yaitu: suhu, $\mathrm{pH}$, dan konduktivitas dengan nilai muatan terbesar adalah suhu air yaitu sebesar 0,95 (Gambar 6). Suhu air sangat memengaruhi pertumbuhan komoditas budidaya. Fluktuasi suhu air yang tidak menentu dan melebihi daya toleransi biota laut da- 
Tabel 3. Hasil analisis komponen utama, nilai akar ciri, variabilitas, dan ragam kumulatif untuk parameter kualitas perairan di Teluk Gerupuk, Lombok Tengah, NTB

Table 3. Results of principal component analysis, eigenvalues, variability, and cumulative of variance for water quality parameters in Gerupuk Bay, Central Lombok, NTB

\begin{tabular}{lcccc}
\hline \multirow{2}{*}{ Peubah (Variable) } & \multicolumn{3}{c}{ Komponen (Component) } \\
\cline { 2 - 5 } & $\mathbf{1}$ & $\mathbf{2}$ & $\mathbf{3}$ & $\mathbf{4}$ \\
\hline Suhu (Water temperature) & $\mathbf{0 . 9 5}$ & -0.03 & 0 & -0.15 \\
$\mathrm{pH}$ & $\mathbf{0 . 8 4}$ & -0.2 & -0.08 & 0.24 \\
Oksigen terlarut (Dissolved oxygen) & 0.18 & 0.14 & -0.12 & $\mathbf{0 . 7 9}$ \\
Padatan terlarut (Total dissolved solid) & 0.07 & $\mathbf{0 . 9 9}$ & -0.02 & 0.01 \\
Konduktivitas (Conductivity) & $\mathbf{0 . 8 8}$ & 0.38 & 0.02 & -0.12 \\
Salinitas (Salinity) & -0.04 & $\mathbf{0 . 9 9}$ & -0.01 & 0.03 \\
Klorofil-a (Chlorophyll-a) & -0.18 & -0.02 & $\mathbf{0 . 6}$ & -0.26 \\
Padatan tersuspensi (Total suspended solid) & 0.26 & -0.06 & $\mathbf{0 . 5 2}$ & -0.23 \\
Amonia/NH ${ }_{3}$-N (Ammonia) & -0.12 & 0.05 & $\mathbf{0 . 6 5}$ & 0.14 \\
Nitrit/NO ${ }_{2}$-N (Nitrite) & -0.07 & 0.03 & -0.76 & -0.21 \\
Fosfat/PO ${ }_{4}$-P (Phosphate) & -0.2 & -0.1 & 0.13 & $\mathbf{0 . 6}$ \\
Nilai akar ciri (Eigenvalue) & 2.67 & 2.11 & 1.65 & 1.24 \\
Ragam (Variance) (\%) & 24.3 & 19.22 & 15.04 & 11.34 \\
Ragam kumulatif (Cumulative of variance) (\%) & 24.3 & 43.53 & 58.58 & 69.93 \\
\hline
\end{tabular}

Keterangan (Note):

Nilai yang bold menandakan nilai PC yang kuat dan sedang (Bold values indicate moderate and strong PC loadings)

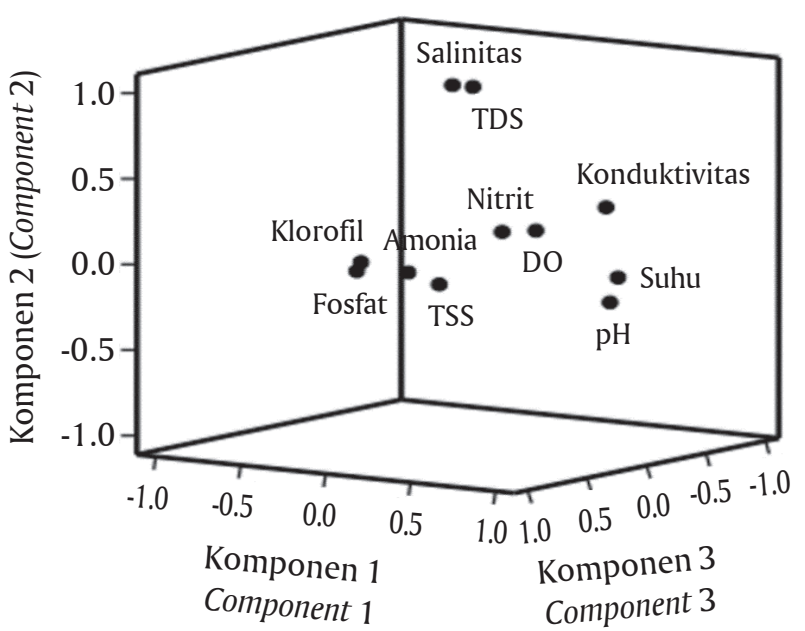

Gambar 6. Plot analisis komponen utama berdasarkan parameter kualitas perairan di Teluk Gerupuk, Lombok Tengah, NTB

Figure 6. Principal component analysis plot for water quality parameters in Gerupuk Bay, Central Lombok, NTB

pat menyebabkan pertumbuhan biota tersebut menjadi terhambat. Fluktuasi suhu di lokasi penelitian sangat memengaruhi pola musim tanam budidaya rumput laut (Radiarta et al., 2013b), dan tingkat pertumbuhan beberapa jenis rumput laut (Erlania \& Radiarta, 2014). Radiarta et al. (2014c) menunjukkan bahwa adanya variasi suhu perairan yang berbeda pada bulan Mei dan September 2013 di Nusa Penida, Bali, dapat memengaruhi tingkat kesesuaian lahan budidaya rumput laut di kawasan tersebut.

PC2 menyumbang $19,22 \%$ dari ragam total data. Dua parameter utama yang membanguni PC2 adalah TDS dan salinitas dengan nilai yang sama, yaitu 0,99 (Gambar 6). Salinitas dan TDS merupakan parameter lainnya yang penting dalam aktivitas budidaya laut. Salinitas yang terlalu rendah $(<28 \mathrm{ppt})$ atau terlalu tinggi (> $35 \mathrm{ppt}$ ) dapat memengaruhi pertumbuhan rumput laut. Salinitas yang sesuai untuk pertumbuhan rumput laut berkisar 28-35 ppt, namun nilai ideal salinitas untuk mendukung pertumbuhan optimal rumput laut adalah berkisar antara 32-34 ppt (Parenrengi et al., 2011).

PC3 memiliki nilai akar ciri sebesar 1,65 dan menyumbang sebesar $15,04 \%$ dari ragam total (Tabel 3). Parameter yang memiliki pengaruh pada PC ini umumnya dikategorikan sebagai parameter kesuburan perairan. Parameter ini sangat bermanfaat untuk budidaya rumput laut dan kekerangan. Nitrit memiliki nilai muatan negatif yang kuat terhadap PC3 sebesar -0,76. Sedangkan amonia, klorofil-a, dan TSS memiliki nilai muatan positif sedang pada PC3, yaitu 0,65; 0,60; dan 0,52 (Gambar 6). DO dan fosfat merupakan parameter yang membangun karakter dari PC4 dengan nilai muatan masing-masing adalah 0,79 (kuat) dan 0,60 (sedang). 
Penggunaan PCA untuk melihat parameter penting kualitas perairan yang memengaruhi kondisi kawasan sangat efektif dilakukan dalam penelitian ini. Empat PC pertama yang dihasilkan dari PCA dapat menjelaskan sekitar 69,93\% dari keragaman total data dari semua parameter (11 parameter) yang digunakan. Dalam hal ini, PCA berfungsi sebagai sarana untuk mengidentifikasi parameter-parameter yang memiliki kontribusi terbesar terhadap variasi temporal dan spasial kualitas perairan di Teluk Gerupuk. Pendekatan serupa juga telah digunakan untuk melihat variasi tersebut terhadap karakteristik kualitas perairan sungai dan pesisir (Simeonov et al., 2003; Varol \& Sen, 2009; Akbal et al., 2011).

\section{Implikasi Pendekatan Statistik Multivariat bagi Pemantauan Karakteristik Perairan}

Kajian kualitas perairan pada suatu kawasan pengembangan perikanan dapat dilakukan melalui beberapa pendekatan mulai dari analisis yang sederhana sampai pada analisis yang kompleks, di antaranya pendekatan tingkat tropik (Pavluk \& Vaate, 2008), indeks kualitas perairan (di antaranya STRORET, water quality index /WQI), atau pendekatan statistik multivariat (Simeonov et al., 2003; Kamble \& Vijay, 2011). Masing-masing pendekatan tersebut mempunyai kelebihan dan kelemahannya. Pendekatan statististik yang umum digunakan adalah analisis faktor, PCA, analisis diskriminan, dan CA. Kelebihan dari analisis multivariat adalah membantu menginterpretasikan data yang kompleks dari hasil pemantauan kondisi kualitas perairan sehingga menjadi lebih mudah dimengerti dan dapat digunakan untuk mengetahui status ekologi dan kualitas perairan dari suatu sistem; serta mempermudah identifikasi faktor/sumber yang memengaruhi sistem perairan (Varol \& Sen, 2009). Analisis statistik ini tentunya harus didukung oleh ketersediaan data yang komprehensif dan representatif baik secara lokasi maupun waktu pengamatan, sehingga dapat menggambarkan kondisi sistem kawasan perairan yang disurvai. Data yang terlalu sedikit (kurang mewakili kondisi lokasi dan waktu pengamatan) tentunya akan berdampak pada hasil analisis yang tidak representatif.

Pada penelitian ini, 16 stasiun pengamatan selama enam bulan (Juli-Desember) program pemantauan telah digunakan untuk analisis multivariat statistik dan menunjukkan hasil yang representatif. Karakteristik kualitas perairan dari hasil analisis statistik ini sangat relevan jika dihubungkan dengan pemanfaatan kawasan perairan untuk budidaya rumput laut (Radiarta et al., 2013b). Jumlah stasiun yang digunakan telah disebar pada seluruh kawasan penelitian dengan jarak antar stasiun yang proporsional, sehingga dapat menangkap karakteristik kawasan per- airan tersebut. Untuk melakukan pemetaan kawasan yang lebih detail, penambahan stasiun dan waktu pengamatan sangat disarankan sehingga dapat menangkap seluruh dinamika sistem perairan yang terjadi. Hasil kajian yang detail tersebut nantinya dapat dijadikan dasar dalam program pemantauan berikutnya sehingga dapat mengefisienkan tenaga, waktu, dan biaya.

\section{KESIMPULAN}

Pemantauan kondisi kualitas perairan sangat penting guna mendukung pengembangan kawasan perairan tersebut. Penelitian ini telah mengaplikasikan statistik multivariat, yaitu analisis klaster dan analisis komponen utama, untuk mendapatkan informasi yang lebih komprehensif tentang kondisi kualitas perairan di Teluk Gerupuk, Nusa Tenggara Barat. Penerapan CA terhadap waktu pengamatan mengelompokkan enam bulan pengamatan menjadi dua periode yaitu periode pertama: bulan Juli-September 2013; dan periode kedua: bulan OktoberDesember 2013. Pengelompokkan ini berhubungan erat dengan pola pengembangan budidaya laut terutama rumput laut. Sedangkan aplikasi CA secara spasial membagi kawasan menjadi tiga kelompok sesuai dengan peruntukan kawasan tersebut. Penerapan PCA sangat jelas menggambarkan parameter yang berpengaruh terhadap variasi kualitas perairan di lokasi penelitian. Terdapat empat komponen utama pertama yang dapat mewakili karakteristik seluruh parameter kualitas perairan (PC1-PC4) di Teluk Gerupuk. Parameter utama yang teridentifikasi memengaruhi karakteristik perairan di Teluk Gerupuk adalah suhu, pH, dan konduktivitas. Pendekatan statistik multivariat yang digunakan dalam penelitian ini dapat berguna bagi evaluasi kualitas perairan pada kawasan pengembangan, dan dapat digunakan untuk mendesain pemantauan kualitas air ke depan yang lebih efisien.

\section{UCAPAN TERIMA KASIH}

Terima kasih disampaikan kepada Balai Budidaya Laut Lombok atas bantuan selama kegiatan di lapangan. Terima kasih juga disampaikan kepada Sdr. Rasidi, M.Si.; Buntaran, M.Si.; Rusman, M.Si.; Seme, dan teknisi dari Balai Budidaya Laut Lombok yang telah membantu kelancaran penelitian di lapangan. Penelitian ini dibiayai oleh DIPA T.A. 2013.

\section{DAFTAR ACUAN}

Akbal, F., Gürel, L., Bahad, T., Gürel, I., Bakan, G., \& Büyüikgüngör, H. (2011). Multivariate statistical techniques for the assessment of surface water quality at the mid-Black Sea Coast of Turkey. Water Air Soil Pollut., 216, 21-37. 
Anonimous. (2012). PIJAR. Evaluasi kegiatan program 2011 dan rencana kinerja tahun 2012. Pemerintah Provinsi Nusa Tenggara Barat. $71 \mathrm{hlm}$.

American Public Health Association [APHA]. (2005). Standard methods for the examination of water and wastewater. $21^{\text {st }}$ Edition. American Water Works Association (AWWA)/American Public Works Association/Water Environment Federation. Washington, USA, 1368 pp.

Beveridge, M.C.M. (1996). Cage aquaculture (Eds. $\left.2^{\text {nd }}\right)$. Fishing News Books LTD. Farnham, Surrey. England, 352 pp.

Butler, E.C.V., Blackburn, S.I., Clementson, A.A., Morgan, P.P., Parslow, J.S., \& Volkman, J.K. (2001). A survey strategy and environmental monitoring network for an estuary supporting finfish cage culture. ICES Journal of Marinene Science, 58, 460468.

Boyacioglu, H. (2006). Surface water quality assessment using factor analysis. Water S.A., 32(3), 389393.

Effendi, H. (2003). Telaah kualitas air: bagi pengelolaan sumber daya dan lingkungan perairan. Kanisius. Yogyakarta, $258 \mathrm{hlm}$.

Erlania \& Radiarta, I N. (2011). Kondisi kualitas perairan di Teluk Lada Pandeglang, Provinsi Banten untuk mendukung budidaya kerang hijau (Perna viridis). J. Ris. Akuakultur, 6(3), 507-519.

Erlania \& Radiarta, I N. (2014). Perbedaan musim tanam terhadap performa budidaya empat varian rumput laut eucheumatoids di Teluk Gerupuk, Nusa Tenggara Barat. J. Ris. Akuakultur, 9(2), 331342.

Erlania, Radiarta, I N., \& Sugama, K. (2014). Dinamika kelimpahan benih lobster (Panulirus spp.) di perairan Teluk Gerupuk, Nusa Tenggara Barat: tantangan pengembangan teknologi budidaya lobster. J. Ris. Akuakultur, 9(3), 475-486.

Huang, J.,Ho, M., \& Du, P. (2011). Assessment of temporal and spatial variation of coastal water quality and source identification along Macau peninsula. Stoch. Environ. Res. Risk. Assess., 25, 353-361.

Iscen, C.F., Emiroglu, O., Ilhan, S., Arslan, N., Yilmaz, V., \& Ahiska, S. (2008). Application of multivariate statistical techniques in the assessment of surface water quality in Uluabat Lake, Turkey. Environmental Monitoring Assessment, 144, 269-276.

Johnson, K., \& McChow, J. (2001). Using ArcGIS spatial analysis. Environmental Systems Research Institute (ESRI), Inc. USA, 236 pp.

Juahir, H., Zain, S.M., Yusoff, M.K., Hanidza, T.I.T., Armi, A.S.M., Toriman, M.E., \& Mokhtar, M. (2011). Spatial water quality asessment of Langat River Basin (Malaysia) using environmentric techniques.
Enviroment Monitoring Assessment, 173, 625-641.

Kamble, S.R., \& Vijay, R. (2011). Assessment of water quality using cluster analysis in coastal region of Mumbai, India. Environ. Monit. Assess., 178, 321332.

Kazi, T.G., Arain, M.B., Jamali, M.K., Jalbani, N., Afridi, H.I., Sarfraz, R.A., Baig, J.A., \& Shah, A.Q. (2009). Assessment of water quality polluted lake using multivariate statistical technique: a case study. Ecotoxixology and Environmental Safety, 72, 301-309.

Kementerian Kelautan dan Perikanan [KKP]. (2014). Blue economy: pembangunan kelautan dan perikanan berkelanjutan. Kementerian Kelautan dan Perikanan Jakarta, 240 hlm.

Kementerian Lingkungan Hidup [KLH]. (2004). Keputusan Menteri Negara Kependudukan dan Lingkungan Hidup No. 51 tahun 2004, tanggal 8 April 2004 tentang baku mutu air laut. Kementerian Lingkungan Hidup. Jakarta, $11 \mathrm{hlm}$.

Kim, J.H., Kim, R.H., Lee, J., Cheong, T.J., Yum, B. W., \& Chang, H.W. (2005). Multivariate statistical analysis to identify the major factors governing roundwater quality in the coastal area of Kimje, South Korea. Hydrol. Process, 19, 1261-1276.

Liu, C.W., Lin, K.H., \& Kuo, Y.M. (2003). Application of factor analysis in the assessment of groundwater quality in a Blackfoot disease area in Taiwan. Science of the Total Environment, 313, 77-89.

Mohamed, I., Othman, F., Ibrahim, A.I.n., Alaa-Eldin, M.E., \& Yunus, R.M. (2015). Assessment of water quality parameters using multivariate analysis for Klang River basin, Malaysia. Environmental Monitoring Assessment, 187, 4182.

Neori, A. (2007). Essential role of seaweed cultivation in integrated multi-trophic aquaculture farms for global expansion of mariculture: an analysis. J. Appl. Phycol., 20, 567-570.

Nontji, A. (2008). Plankton laut. Pusat Penelitian Oseanografi. Lembaga Ilmu Pengetahuan Indonesia (LIPI). LIPI Press, $331 \mathrm{hlm}$.

Parenrengi, A., Rachmansyah, \& Suryati, E. (2011). Budidaya rumput laut penghasil karaginan (Karaginofit). Balai Riset Perikanan Budidaya Air Payau, Badan Penelitian dan Pengembangan Kelautan dan Perikanan, Kementerian Kelautan dan Perikanan. Jakarta, 54 hlm.

Pavluk, T., \& Vaate, A. (2008). Trophic index and efficiency. Ecological Indicators. Elsevier, p. 36023608.

Pong-Masak, P.R., Tjaronge, M., \& Madeali, M.I. (2009). Musim tanam rumput laut di perairan Tonra Kabupaten Bone, pantai Timur Sulawesi Selatan. Prosiding Forum Inovasi Teknologi Akuakultur 2009. Pusat Riset Perikanan Budidaya, Badan 
Riset Kelautan dan Perikanan. Jakarta, hlm. 413421.

Radiarta, I.N., \& Rasidi. (2012). Analisa spasial kondisi kualitas perairan untuk mendukung budidaya rumput laut di Teluk Gerupuk Kabupaten Lombok Tengah Provinsi Nusa Tenggara Barat. Prosiding Seminar Nasional Perikanan Indonesia 2012. Sekolah Tinggi Perikanan. Jakarta, hlm. 88-94.

Radiarta, I N., Erlania, Rasidi, Ardi, I., Sugama, K., Suyawati, S.H., \& Ginantra, K. (2013a). Kajian pengembangan sistem perikanan budidaya pada komoditas unggulan berbasis kawasan. Laporan akhir penelitian. Pusat Penelitian dan Pengembangan Perikanan Budidaya (tidak dipublikasi). 154 hlm.

Radiarta, I.N., Erlania, \& Rusman. (2013b). Pengaruh iklim terhadap musim tanam rumput laut, Kappaphycus alvarezii, di Teluk Gerupuk, Kabupaten Lombok Tengah, Nusa Tenggara Barat. Jurnal Riset Akuakultur, 8(3), 453-464.

Radiarta, I N., Erlania, Sugama, K., Yudha, H.T., \& Wada, M. (2014a). Frequent monitoring of water temperature in Pegametan Bay, Bali: a preliminary assessment towards management of marine aquaculture development. Indonesian Aquaculture Journal, 9(2), 185-193.

Radiarta, I N., Erlania, \& Sugama, K. (2014b). Budidaya rumput laut, Kappaphycus alvarezii secara terintegrasi dengan ikan kerapu di Teluk Gerupuk Kabupaten Lombok Tengah, Nusa Tenggara Barat. Jurnal Riset Akuakultur, 9(1), 125-134.

Radiarta, I N., Erlania, \& Rasidi. (2014c). Analisis pola musim tanam rumput laut, Kappaphycus alvarezii melalui pendekatan kesesuaian lahan di Nusa
Penida, Bali. J. Ris. Akuakultur, 9(2), 319-330.

Radiarta, I N., \& Erlania. (2014). Analisis spasial dan temporal kesesuaian lahan budidaya rumput laut, Kappaphycus alvarezii di Teluk Gerupuk Lombok Tengah Provinsi Nusa Tenggara Barat. Prosiding Forum Inovasi Teknologi Akuakultur. hlm. 437-444.

Ragno, G., De Luca, M., \& Ioele, G. (2007). An application of cluster analysis and multivariate classification methods to spring water monitoring data. Mathematical Journal, 87, 119-127.

Shrestha, S., \& Kazama, F. (2007). Assessment of surface water quality using multivariate statistical techniques: A case study of the Fuji River Basin; Japan. Environmental Modelling \& Software, 22, 464475.

Shuhaimi-Othman, M., Lim, E.C., \& Mushrifah, I. (2007). Water quality changes in Chini Lake, Pahang, West Malaysia. Environmental Monitoring Assessment, 131, 279-292.

Singh, K.P., Malik, A., Mohan, D., \& Sinha, S. (2004). Multivariate statistical techniques for the evaluation of spatial and temporal variations in water quality of Gomti river (India): a case study. Water Res., 38, 3980-3992.

Simeonov, V., Stratis, J.A., Samara, C., Zachariadis, G., Voutsa, D., Anthemidis, A., Sofonious, M., \& Kouimtzis, Th. (2003). Assessment of the surface water quality in Northern Greece. Water Research, 37, 4119-4124.

Varol, M., \& Sen, B. (2009). Assessment of surface water quality using multivariate statistical techniques: a case study of Behrimaz Stream, Turkey. Environ. Monit. Assess., 159, 543-553. 